\title{
Cytotoxicity Study of Nigella Sativa and Zingiber zerumbet Extracts, Thymoquinone and Zerumbone Isolated on Human Myeloid Leukemia (HL60) Cell
}

\author{
M.N. Norfazlina ${ }^{1,2, *}$, M.Y. Farida Zuraina ${ }^{1}$, Rajab N.F ${ }^{2}$, S. Mohd Nazip ${ }^{1}$, A.R. Rumiza ${ }^{1}$, C.F. \\ Suziana Zaila ${ }^{1,2,}$ L. Lek Mun ${ }^{2}$, N. Nurshahirah ${ }^{1,2}$ and L. Florinsiah ${ }^{1,2}$ \\ ${ }^{I}$ Faculty of Applied Sciences, Universiti Teknologi MARA, 40450 Shah Alam, Selangor, Malaysia \\ ${ }^{2}$ Toxicology Laboratory, Faculty of Health Sciences, Universiti Kebangsaan Malaysia, Jalan Raja Muda Abdul Aziz, \\ 50300 Kuala Lumpur, Wilayah Persekutuan, Malaysia
}

\begin{abstract}
The cytotoxicity effects of Nigella sativa (Ns) and Zingiber zerumbet (Zz) extracts on acute Human myeloid leukemia cell line (HL60) are reported. The HL60 cell line was purchased from the American Tissue Culture Company (ATCC) was treated with petroleum ether (PE) and aqueous (AQ) extracts of Ns and Zz extracts of ethanol (ET) and Hexane (HEX). In an attempt to explain cytotoxicity effects of Ns and Zz extracts by 3-[4,5-dimethylthizol-2-yl]-2,5diphenyltetrazolium bromide (MTT) assay, we examined the effects of Doxorubin (Dox) on their sensitivity as anticancer drugs which was assigns as a positive control in this experiment. Different plant species has different component as bioactive compound. The different activity is present by the different compound. The cytotoxicity effects of plant species are differed based on the presence of their bioactive compound. Therefore, this study was carried out to compare the cytotoxicity effects of Nigella sativa (Ns) and Zingiber zerumbet $(\mathrm{Zz})$ extracts on HL60 cell lines since both of these plants are from different species. Furthermore, this study was also to compare the cytotoxicity effect of plant extract and its compound which are Ns extract and thymoquinone, $\mathrm{Zz}$ extract and zerumbone. In this study, Hexane extract of $\mathrm{Zz}$ significantly dropped off the percentage of cell viability of HL60 cell by giving the lowest $\mathrm{IC}_{50}$ value which is $63.72 \mathrm{ug} / \mathrm{ml}$ $(\mathrm{p}<0.05)$. Hexane extracts is more effective solvent compared to ethanol that gave $\mathrm{IC}_{50}$ value of $345.3 \mathrm{ug} / \mathrm{ml}$. Ns extract is less effective on HL60 cell lines that gives the highest $\mathrm{IC}_{50}$ value which are $654 \mathrm{ug} / \mathrm{ml}$ for PE and greater than $1000 \mathrm{ug} / \mathrm{ml}$ for AQ. It is concluded that the cytotoxicity effects of $\mathrm{Zz}$ is more proficient as compared to Ns in this cell. HEX extract is more appropriate solvent for the $\mathrm{Zz}$ extraction that gave the lowest $\mathrm{IC}_{50}$ as compared to $\mathrm{ET}$. In addition, PE extract shows the characteristic of more appropriate solvent for Ns extraction compared to AQ solvent since gives the lowest IC $\mathrm{I}_{50}$ value. On the other hand, both of plant species showed apoptosis as mode of cell death.
\end{abstract}

Keywords: Human myeloid leukemia (HL60), Nigella sativa (Ns), Zingiber zerumbet (Zz), 3-[4,5-dimethylthizol-2-yl]-2,5diphenyltetrazolium bromide (MTT), Apoptosis.

\section{INTRODUCTION}

During the last 20 years, more than $25 \%$ of drugs were derived from plant species while the other $25 \%$ were chemically altered natural product. It was highlighted that only $5-15 \%$ of approximately 250,000 higher plants have been investigated for bioactive compounds $[1,2]$. The advantages of using such compounds for cancer healing are due to their relatively non-toxic nature and the availability in an ingestive form. Many scientists in Malaysia have found plant species that have potential value and can be used as drugs to treat a variety of diseases. Malaysia has about 1300 species from 12000 of flowering plant species that can give medicinal values [3]. Nigella sativa $(\mathrm{Ns})$ or black cumin is an annual herb that belongs to Ranunculaceae family, which grows in countries bordering the Mediterranean sea, Pakistan

*Address correspondence to this author at the School of Biological sciences, Universiti Teknologi Mara, 40450 Shah Alam, Selangor;

Tel: 014216 0210;Fax: 03-55444562;E-mail: funfazzy@yahoo.com and Indian. For thousands of years, the seed of this plant known as black seed and has been used as a spice and food preservative as well as a protective in superstition and in traditional medicine for the treatment of numerous diseases in many Asian, Middle Eastern. Moreover, black seed is referred to by the prophet Mohammed as having healing power but cannot prevent aging or death. The seeds are commonly eaten alone or in combination with honey for the treatment of bronchial asthma and used as preservative in food preparations [4].

The oil is prepared by compressing the seeds of Ns and is used for cooking. Generally, $30 \%$ of the seed is fixed oil and 0.40 to $0.45 \%$ of volatile oil. Several studies were reported that 18.4 to $24 \%$ of volatile oil is thymoquinone $[5,6]$. There is an emergent interest to study the therapeutic potential of Ns crude extract or pure compound in cancer therapy. Previous research reported about the cytotoxicity effects of TQ on several cancer cells such as human colon cancer cell [7], human pancreatic cancer cell [8], hepatocellular carcinoma [9] and etc. Zingiber zerumbet (Zz) or locally 
known as 'Lempoyang' is a wild ginger that belongs to Zingiberaceae family [10]. Zingiberaceae is frequently used as a raw material for formulation of traditional medicine that is commonly sold in local market $[11,12]$.

According to several studies conducted by $[13,14]$ has been proven to contain suppressive effect which was conducted by bioactive compound, zerumbone and able to exert as anti tumor. However, to our best of knowledge, there is no study that shows anticarcinogenic effects of PLE extract of $\mathrm{Ns}$ and $\mathrm{Zz}$ on human myeloid leukemia cell (HL60). Pressurize Liquid Extraction (PLE) has received an attention as an alternative method to organic solvent extraction and has been shown to be an ideal for extracting the food. PLE is simple to use and using hot and high pressurized liquid solvent that let to decrease the time and solvent amount [15]. In this study, we examined the effectiveness of Ns and $\mathrm{Zz}$ as anticancer and its mode of cell death in comparison with TQ and ZE on HL60 cells as targeted cell. In addition, we also examined the effect of Ns and $\mathrm{Zz}$ on untargeted normal cell which is Chinese hamster lung (V79) cell line.

\section{MATERIALS AND METHODS}

\subsection{Collection of Raw Material}

Ns seed was purchased at Klang wet market and stored in the dark in room temperature whereas $\mathrm{Zz}$ was purchased at Chow Kit wet market, Kuala Lumpur. $\mathrm{Zz}$ is obtained from the same source which is Bentong, Pahang. A human myeloid leukemia (HL60) cell line and V79 cell line were donated from the Faculty of Health Sciences, Universiti Kebangsaan Malaysia (UKM) and stored in $-80^{\circ} \mathrm{C}$.

\subsection{Pressurize Liquid Extraction (PLE) Method}

The seed of Ns was dried in an oven at $40{ }^{\circ} \mathrm{C}$ for 3 days and Ground into powder. Furthermore, rhizome of $\mathrm{Zz}$ was chopped into a small piece and dried in the oven at the temperature of $45^{\circ} \mathrm{C}$ for 3 days. The dried rhizome of $\mathrm{Zz}$ was ground into powder. In this study, Pressurize Liquid Extraction (PLE) method was applied for the extraction process. This method was use Acceleration Solvent Extraction (ASE) machine as equipment for extraction. This extraction method took 10 minutes of static time for one cycle with $1500 \mathrm{psi}$ of pressure and $80^{\circ} \mathrm{C}$ of temperature. The extracts produced are light, temperature and moisture sensitive, therefore the extracts were stored at $-20{ }^{\circ} \mathrm{C}$ in dehydrogenaze potassium bicarbonate [16].

\subsection{Nigella sativa and Zingiber zerumbet, Thymoquinone and Zerumbone Preparation}

The extracts of Ns and $\mathrm{Zz}$ produce were dissolved in the suitable solvent and made up $200 \mathrm{mg} / \mathrm{ml}$ stock solution. PE extract of Ns was dissolved in $100 \%$ ethanol and AQ extract of Ns was dissolved in distilled water and were stored at $20{ }^{\circ} \mathrm{C}$. HEX and ET extracts of $\mathrm{Zz}$ were dissolved in dimethylsulphoxide (DMSO) and also stored at $-20{ }^{\circ} \mathrm{C}$. they were diluted further to a concentration of $1000 \mathrm{ug} / \mathrm{ml}$ in IMEM using 20ul of stock solution in 2000ul IMEM as working solution. It was then serial diluted further to concentration of $500,250,125$ and $0 \mathrm{ug} / \mathrm{ml}$ in $2000 \mathrm{ul}$ IMEM. The similar method was used for the preparation of thymoquinone and zerumbone stock solution $(10 \mathrm{mM})$ and working solution. Thymoquinone (TQ) is the pure compound of Ns appears as yellow solid and purchased from Sigma Aldrich. On the other hand, the pure compound of zerumbone (ZE) appears as white solid and was isolated from Zingiber zerumbet. Zerumbone was donated by postgraduate student from faculty of health sciences, University Kebangsaan Malaysi. Both TQ and ZE were dissolved in DMSO as the preeminent solvent. The dose range for TQ is 0 to $100 \mathrm{uM}$ whereas 0 to $200 \mathrm{uM}$ for $\mathrm{Zz}$. The extracts and compounds are light sensitive and need to be stored in the dark

\subsection{Cell Culture and MTT Cytotoxicity Assay}

Human Leukemia cell lines HL60 cell, were cultured by initially seeding $1 \times 10^{5}$ cells $/ \mathrm{ml}$ of fresh Dulbecco's Modified Eagle Medium (IMEM) supplemented with 20\% Fetal Bovine Serum (FBS), 10\% Penicillin-Streptomycin in a humidified atmosphere of $95 \%$ air, $5 \% \mathrm{CO}_{2}$, at $37{ }^{\circ} \mathrm{C}$. To avoid possible effects of cell density on cell growth and survival, cells were maintained when cell density reach $8 \times 10^{5}$ not exceed $1 \times 10^{6}$ cells $/ \mathrm{ml}$. Cell were poured into centrifuge tube and centrifuged at $1500 \mathrm{~g}$ for 5 minutes. Five $\mathrm{ml}$ of warm media was added in the pellet and gently resuspended. Cells were seeded at $1 \times 10^{5}$ cells $/ \mathrm{ml}$ with daily adjustment of cell concentrations by adding fresh medium. At assay time, cells were collect, $20 \mathrm{ul}$ of cell mixed with $80 \mathrm{ul}$ of trypan blue dye and manually counted. Actual cell numbers were calculated by multiplying diluted times compared with initial cell numbers. Each well of 96 well plates were seeded with $100 \mathrm{ul}$ of $1 \times 10^{6}$ cells and added with 100ul of treatment. After 24hours, 20ul of MTT solution were added into each well and put in the incubator for 4 hours. Furthermore, 200ul of DMSO were added into each well for 15 minutes. Cell viability was read using microplate reader at 570nm [17]. Cell viability was calculated using an equation (1) [18]. The effects of extracts were expressed by IC50 values calculated from dose- $\%$ cell viability curve. Mean while, Chinese hamster lung (V79) cells were grown in DMEM medium supplemented with $1 \%$ penicillinstreptomycin and 10\% Fetal Bovine Serum (FBS) in a humidified atmosphere in a $5 \% \mathrm{CO}_{2}$ incubator.

$\%$ cell survival $=(\mathrm{At}-\mathrm{Ab}) /(\mathrm{Ac}-\mathrm{Ab}) \times 100(1)$

At $=$ Absorbance of Test,

$\mathrm{Ab}=$ Absorbance of Blank (Media),

$\mathrm{Ac}=$ Absorbance of control (cells)

\subsection{Apoptosis Induction and Investment}

Apoptosis was induced by an addition of $670 \mathrm{ug} / \mathrm{ml}$ of $\mathrm{Ns}$ and $60 \mathrm{ug} / \mathrm{ml}$ of $\mathrm{Zz}$ treated on HL60 cell lines. Positive control was treated with $5 \mathrm{uM}$ etoposide. For suspension cells of HL60, cell density was $1 \times 10^{6}$ per $\mathrm{ml}$ at the onset of treatment and was left for 24 hours. Apoptosis was assessed in suspension cell by annexin V-FITC as described by [19]. After 24 hours of treatment, the cells were harvested and centrifuged at $15000 \mathrm{~g}$ for 5 minutes. The pellet was added with PBS and centrifuged again. The pellet was added with $150 \mathrm{ul}$ annexin buffer and then added with $2.5 \mathrm{ul}$ annexin $\mathrm{V}$ FITC and left for 15 minutes. After that, 10ul PI was added and let it for 2 minutes. After 2 minutes, 350 ul of annexin 
Table 1. The Cytotoxicity Effect of Ns Seed and Zz Rhizome Extracts, their Compound TQ and ZE. The Cytotoxicity Effectiveness was Compared with Extablish Cytotoxicity Agent DOX

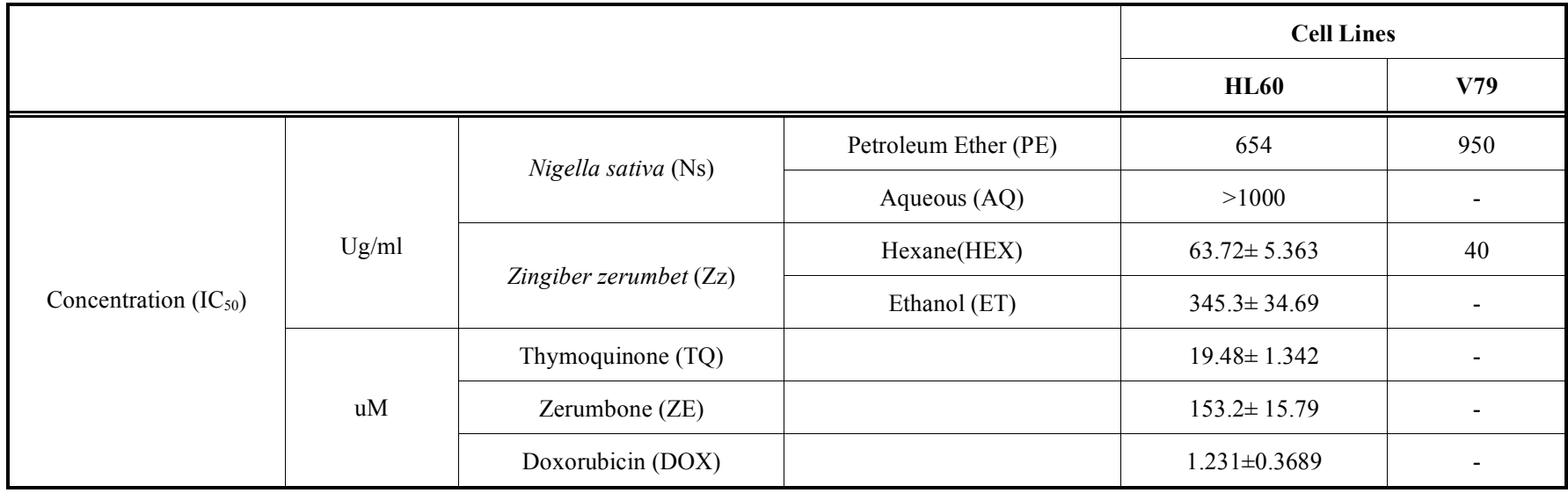

buffer was added. The percentage of annexin $\mathrm{V}$ positive cells was determined by flow cytometry.

\subsection{Statistical Analysis}

The results are expressed as the mean \pm standard error of the mean (SEM). The Student t-test was used to determine statistical significance $(\mathrm{p} \leq 0.05)$.

\section{RESULT}

\subsection{Growth and Proliferation Inhibition}

The cytotoxicity effects of crude extract and its pure compound were summarized in Table 1. The table shows Ns and $\mathrm{Zz}$ crude extracts have a different cytotoxicity on the cell lines after 24 hours of treatment. The MTT assay of crude extract shows that PE extract of Ns and both HEX and ET extracts of Zz exhibit cytotoxicity effects against HL60 cell. PE, HEX and ET show cytotoxicity effects with $\mathrm{IC}_{50}$ values at $654 \mathrm{ug} / \mathrm{ml}, 63.72 \pm 5.363 \mathrm{ug} /$ and $345.3 \pm 34.69 \mathrm{ug} / \mathrm{ml}$. Aqoues extracts of $\mathrm{Ns}$ is more resistance to $\mathrm{HL} 60$ with $\mathrm{IC}_{50}$ more than $1000 \mathrm{ug} / \mathrm{ml}$. On the other hand, the $\mathrm{IC}_{50}$ of TQ and ZE (pure compound) on HL60 cells compared to untreated control cells after 24 hours of treatment were 19.48土 $1.342 \mathrm{uM}$ and $153.2 \pm 15.79 \mathrm{uM}$. Positive control show more potent on HL60 cell with $\mathrm{IC}_{50} 1.231 \pm 0.3689 \mathrm{uM}$. The $\mathrm{IC}_{50}$ of the crude extract, pure compound and positive control are shown in (Fig. 1). Fig. (2) shows cytotoxicity effects of Ns and $\mathrm{Zz}$ on untargeted normal V79 cells. PE extract of Ns is more resistance on V79 cells compared to HL60 cells with $\mathrm{IC}_{50}$ was $950 \mathrm{ug} / \mathrm{ml}$. Vice versa, HEX extract of $\mathrm{Zz}$ is more cytotoxic on $\mathrm{V} 79$ cells with $\mathrm{IC}_{50}$ is $40 \mathrm{ug} / \mathrm{ml}$ compared to HL60 cells.

\subsection{PE Extract of Ns and HEX Extract of $\mathrm{Zz}$ Induce Apoptosis}

Fig. (3) shows the effects of $\mathrm{Ns}$ and $\mathrm{Zz}$ on the cells apoptosis of HL60 cell for 24 hours. Treatment of HL60 cells with $670 \mathrm{ug} / \mathrm{ml} \mathrm{PE}$ extract of Ns resulted in no necrotic cells after 24 hours. However the apoptotic effect by Ns was much more dramatic with near $100 \%$ of the cells become apoptotic after 24 hours as compared to control. On the other hand, treatment of HL60 cells with $60 \mathrm{ug} / \mathrm{ml}$ HEX extract of $\mathrm{Zz}$ resulted $4.3 \%$ of cells become necrotic after 24 hours compared to control. However, treatment $\mathrm{Zz}$ for 24 hours had induced $50 \%$ of apoptotic cells. There are more significant apoptotic cell deaths in Ns treatment as compared to $\mathrm{Zz}$ treatment on HL60 cells. For positive control, the treatment with $5 \mathrm{uM}$ etoposide, was induced $44 \%$ apoptosis and $10 \%$ necrotic cell after 24 hour treatment compared to control

\subsection{Comparison Between MTT Assay and FITC Annexin-V Flow Cytometry}

Fig. (4) show the percentage cell death of HL60 for both $\mathrm{Ns}$ and $\mathrm{Zz}$ treatment through MTT assay and VIT-C annexin-V flow cytometry analysis. For Ns extract treatment, analysis through VIT-C annexin-V show significant different $(\mathrm{p} \leq 0.05)$ in percentage of cell death compared to MTT assay. The percentage of cell death is much more dramatic in VIT-C annexin-V with $90 \%$ of cell death and only $37 \%$ cell death showed in MTT assay. On the other hand, analysis of MTT assay and VIT-C annexin-V of $\mathrm{Zz}$ extract treatment show no significant different $(\mathrm{p} \geq 0.05)$ as the percentage of cell death is $41 \%$ and $51 \%$.

\section{DISCUSSION}

There has been augmented attention in the use of natural resources with chemopreventive and chemotherapeutic effects in the treatment of cancers. Ns and $\mathrm{Zz}$ conventionally prepared crude extract has shown anti proliferation effect in vitro against different cancer cell lines. However, the effects of its PLE extract against cancer cells are yet to be determined. PLE is an attractive option to conventional methods of extraction due to unlimited temperature and pressure, reduced solvent utilization and shorter extraction time [20]. These advantages of PLE extraction may provide an appropriate method and able to enhance extraction process in the production of food and pharmaceuticals. The aim of using different solvents for extraction is to attract the chemical components in the seed of Ns and rhizome of $\mathrm{Zz}$ based on the principle of mass transfer of substance into the solvent component, where the movement began to occur at the interface layer and then diffuses into the solvent [21]. Petroleum ether is non-polar solvent used to fascinate non polar compound such as wax, fat and lipids which can hamper during separation process as well to eradicate resins which can interrupt the extraction [22]. Vice versa, water extract is polar solvent and used to attract polar component. 


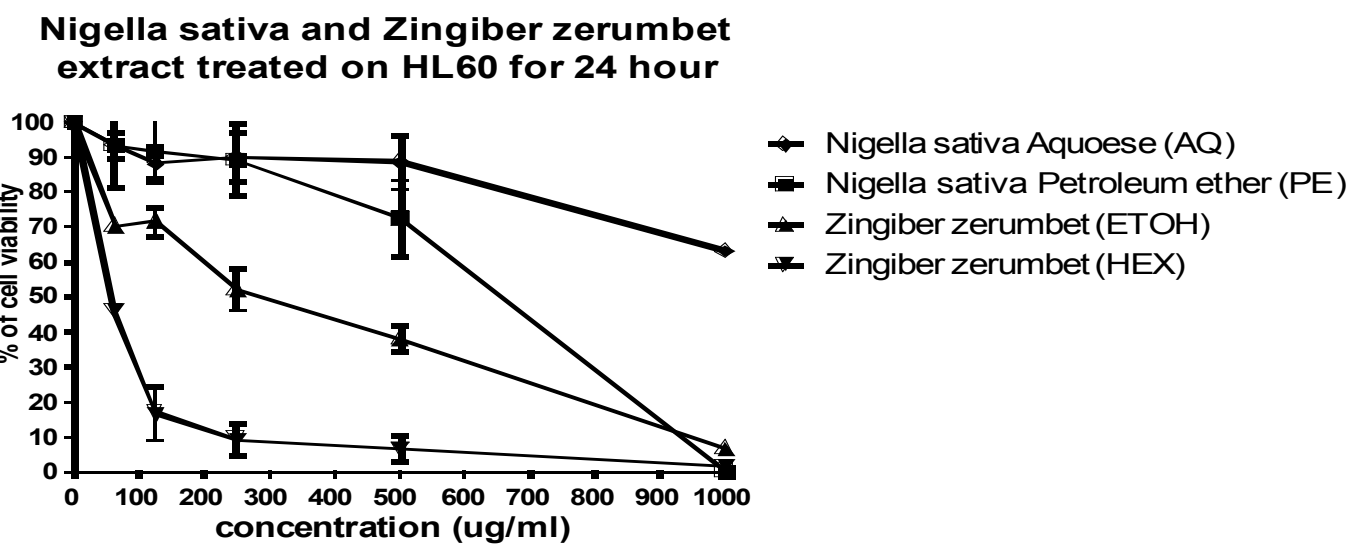

(A) Crude extracts of Ns and $\mathrm{Zz}$

Zerumbone treated on HL60 cell Iine for 24 hour

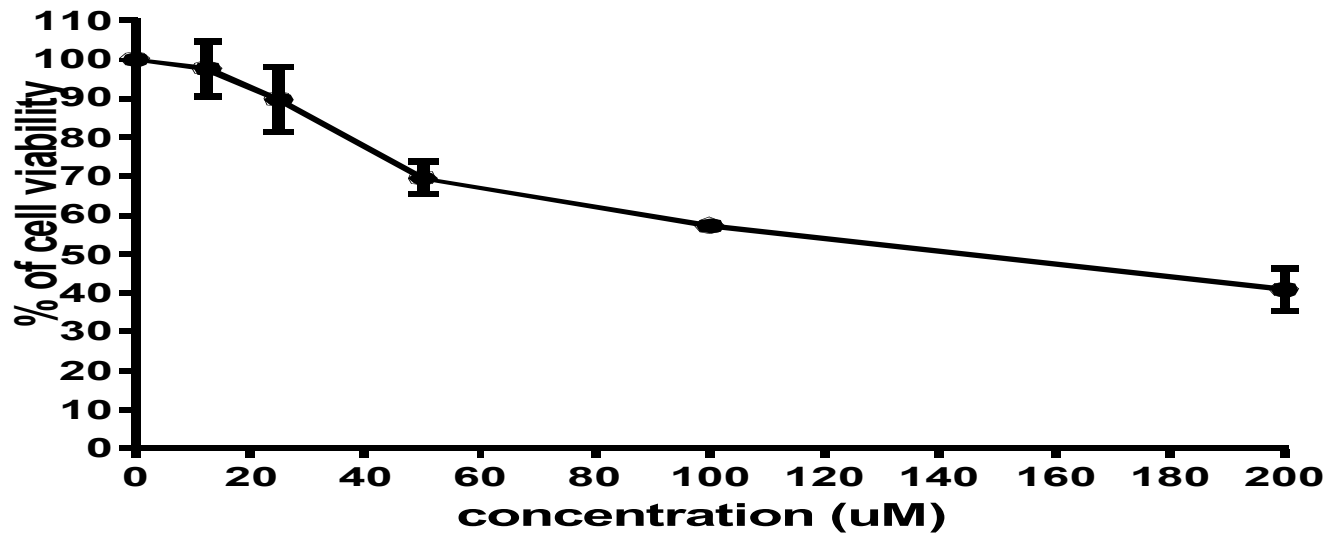

(B) Zerumbone (Pure compound Zz)

\section{Thymoquinone treated on HL60 cell line for $\mathbf{2 4}$ hour}

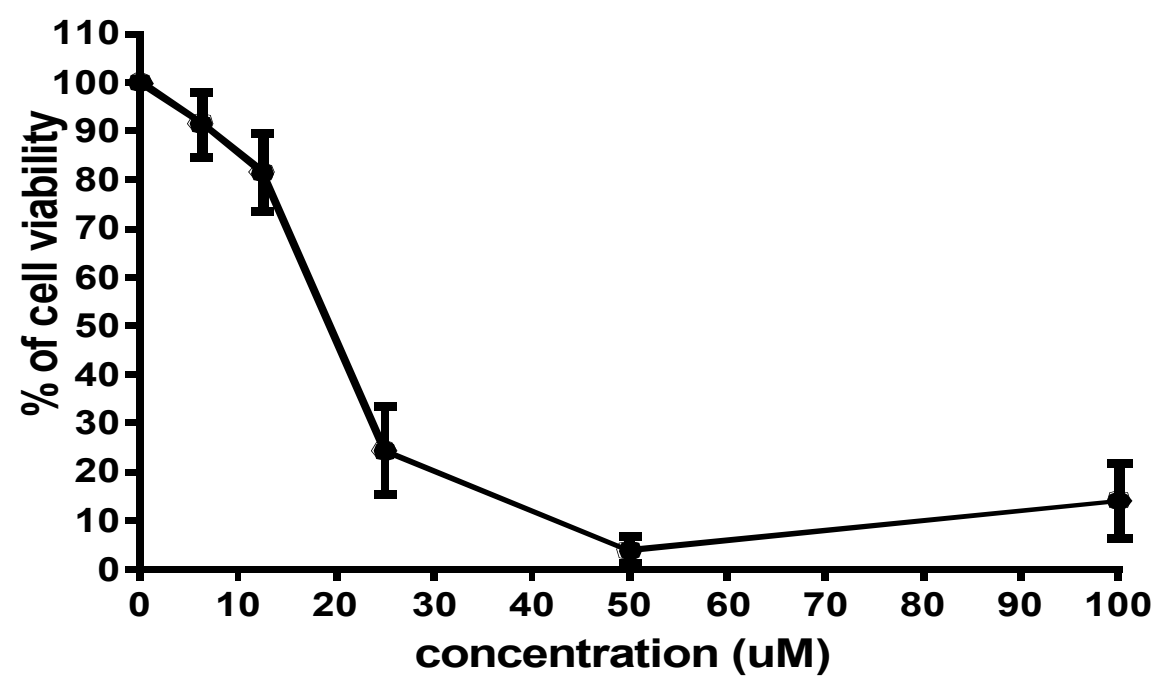

(C) Thymoquinone (Pure compound Ns) 
Fig. (1). Contd....

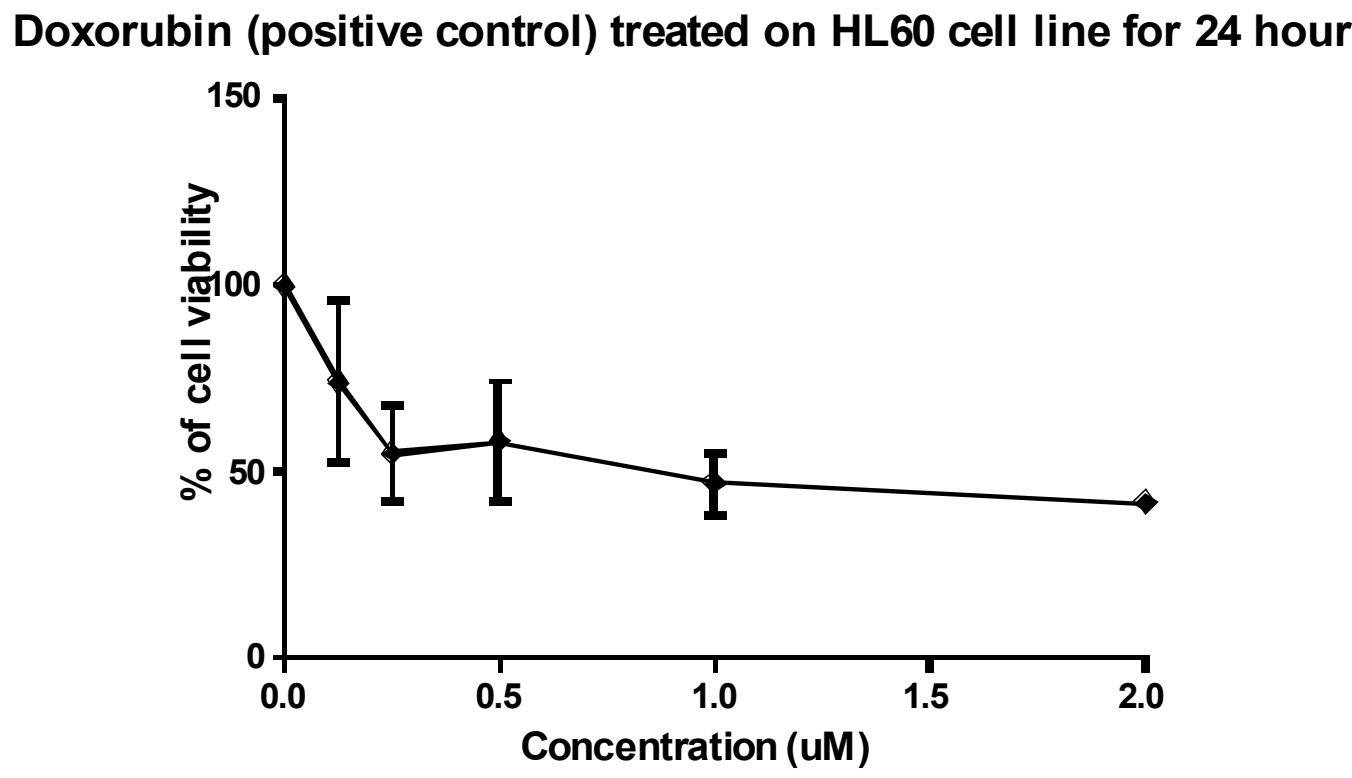

(D) Doxorubin (Positive control)

Fig. (1). Reduction of percentage of human myeloid leukemia (HL60) viable cells with (A) Crude extracts of Ns and Zz (B) Zerumbone (C) Thymoquinone (D) Doxorubin. The cells were treated for 24 hours with various concentrations of treatment. Levels of cell viability were measured using MTT assay. The viability of untreated control cells was defined as $100 \%$. The concentration that gave $50 \%$ inhibition of cell growth $\left(\mathrm{IC}_{50}\right)$ was calculated.

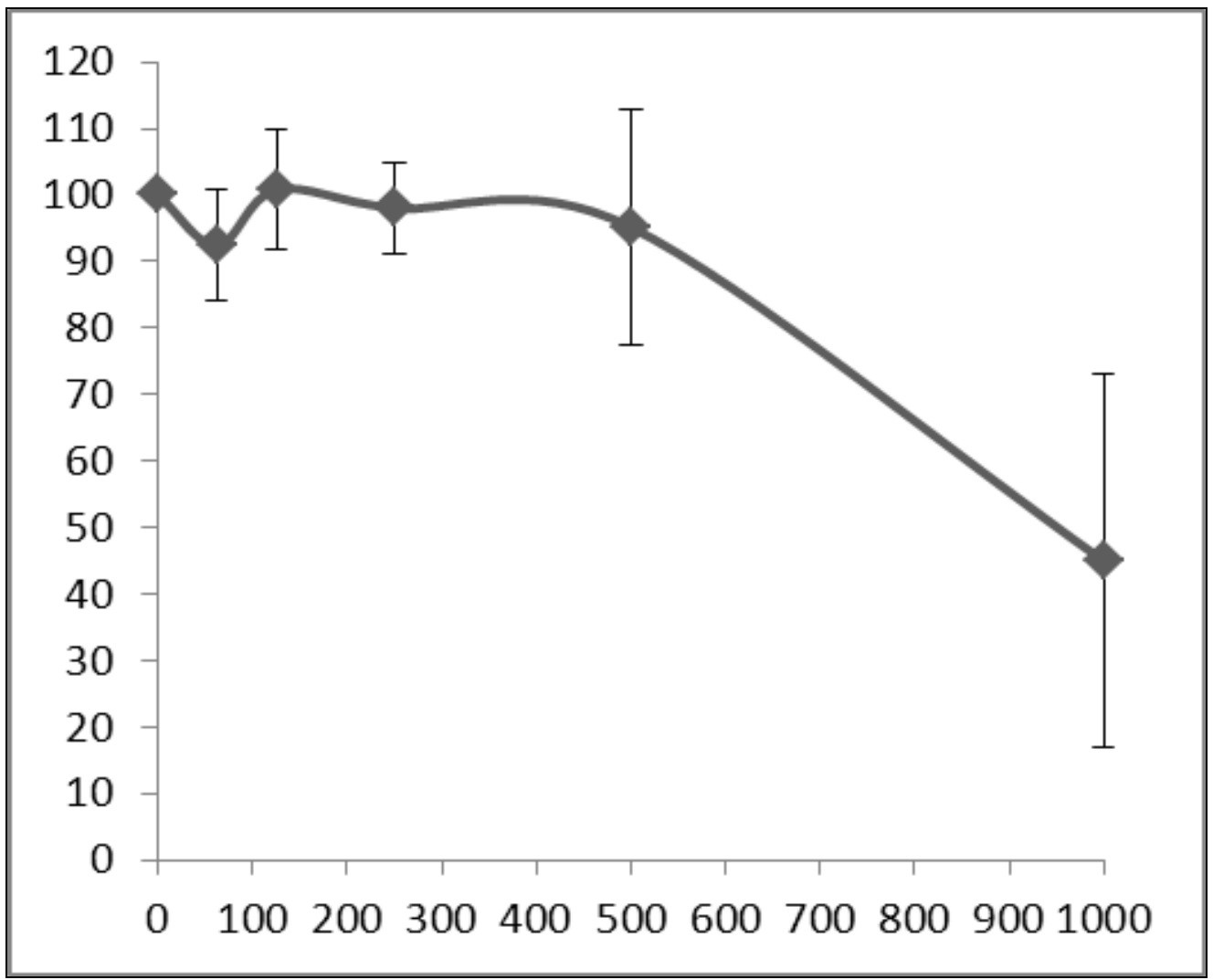

(A) PE extract of Ns 
Fig. (2). Contd...

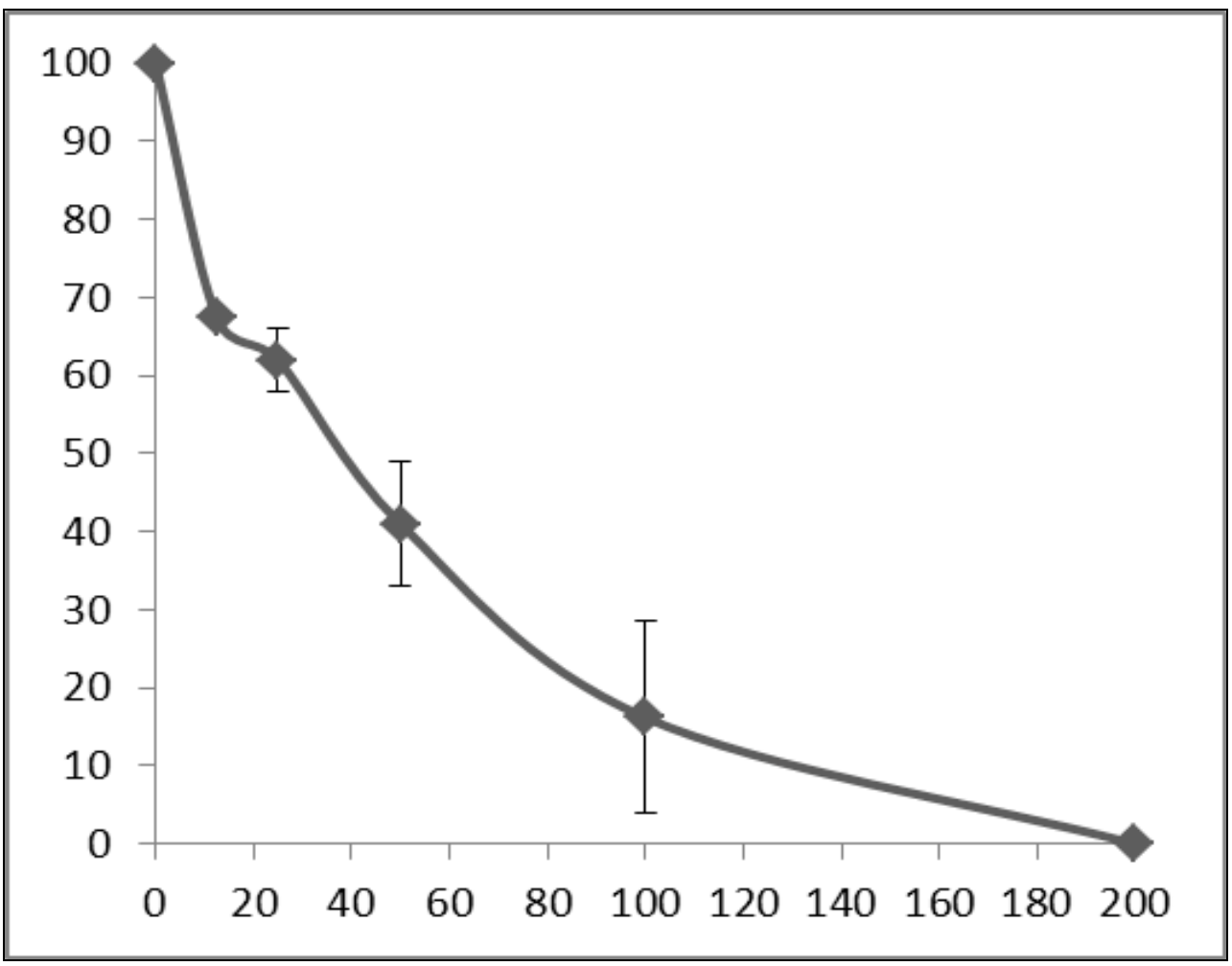

(B) HEX extract of $\mathrm{Zz}$

Fig. (2). Reduction of percentage of chinese hamster lung (V79) viable cells with (A) PE extract of Ns and (B) HEX extract of Zz. The cells were treated for 24 hours with various concentrations of treatment. Levels of cell viability were measured using MTT aasay. The viability of untreated control cell was defined as $100 \%$. The concentration that gave $50 \%$ inhibition of cell growth $\left(\mathrm{IC}_{50}\right)$ was calculated. The $\mathrm{IC}_{50}$ of the treatment on V79 cell was compared with $\mathrm{IC}_{50}$ on HL60 cells to evaluate its cytotoxic on normal untargeted cells.

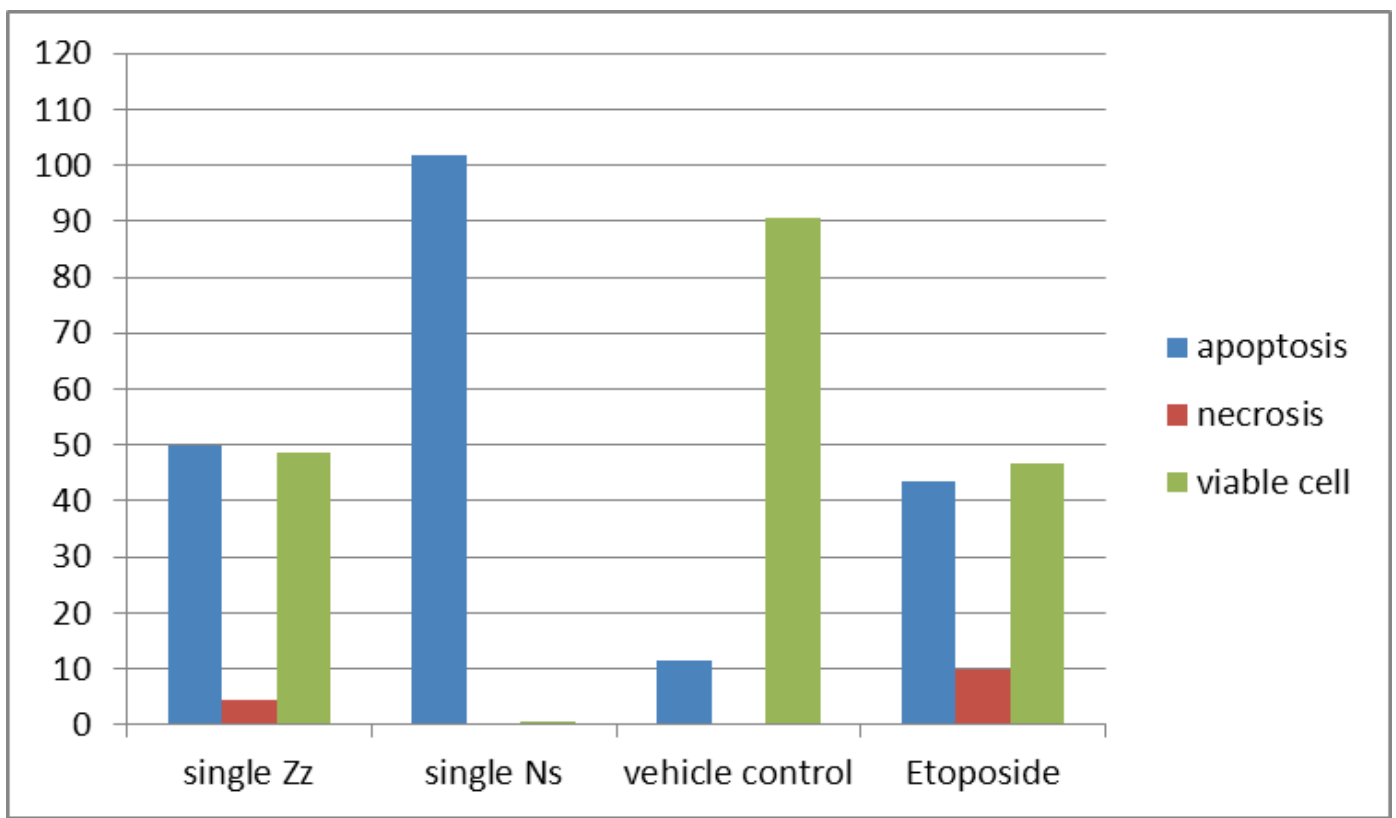

Fig. (3). Effects of PE extract of Ns and HEX extract Zz on cell apoptosis in HL60 cell determined by flow cytometric analysis. The cells were treated with the concentration of $60 \mathrm{ug} / \mathrm{ml}$ of $\mathrm{Zz}$ and $670 \mathrm{ug} / \mathrm{ml}$ of Ns of MTT assay for 24 hours. Percentage of cell population in each quadrant was computed using the Microsoft excel software. 


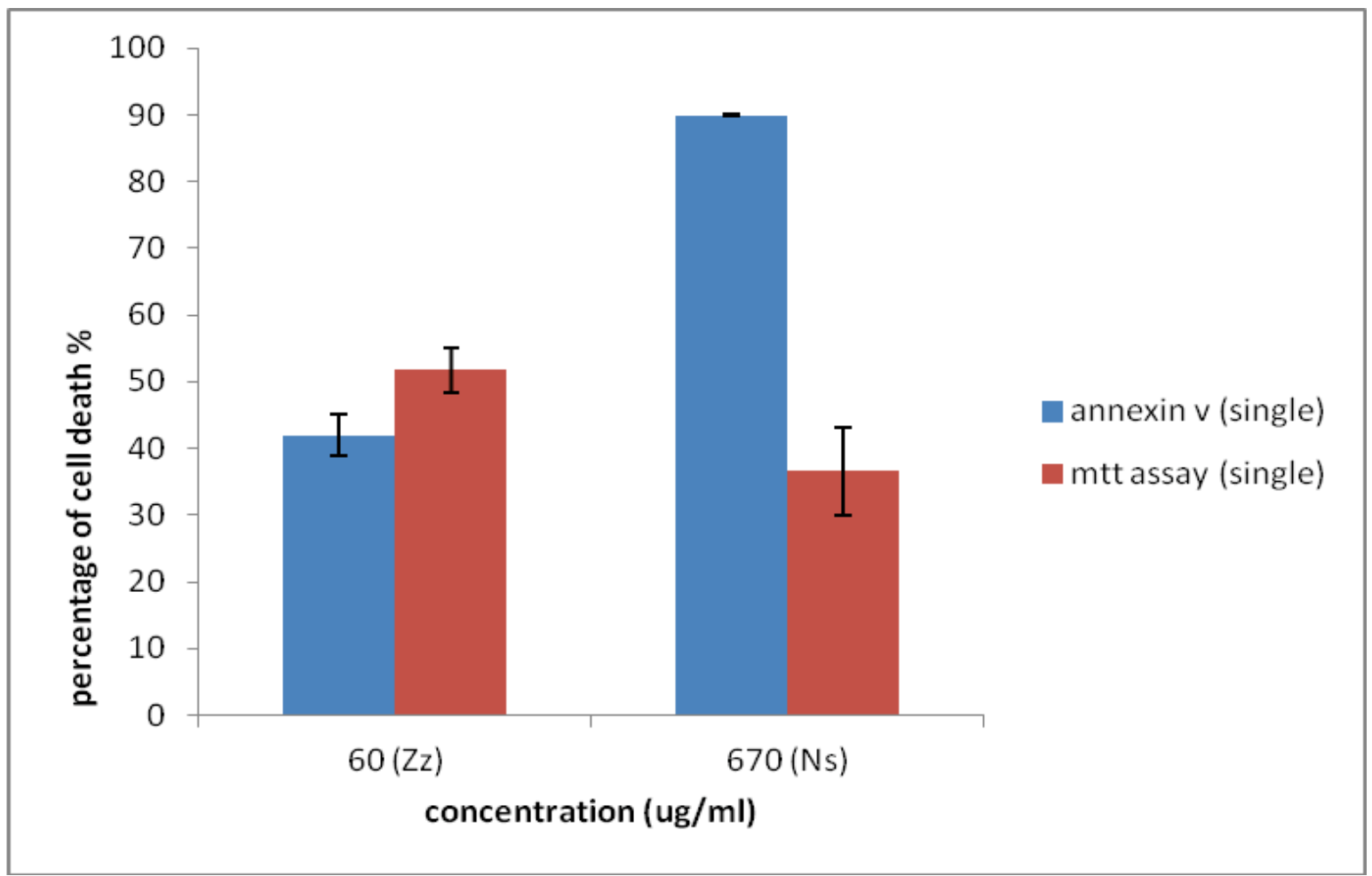

Fig. (4). Comparison of the effects of PE extract of Ns and HEX extract of Zz on the percentage of cell death in HL60 cell through MTT assay and VIT-C annexin-V flow cytometry analysis. The cells were treated with concentration of $60 \mathrm{ug} / \mathrm{ml} \mathrm{of} \mathrm{Zz} \mathrm{and} 670 \mathrm{ug} / \mathrm{ml} \mathrm{of} \mathrm{Ns}$ for 24 hours.

Phytochemical screening by [23] revealed that aqueous extract of Ns contain alkaloids, flavonoids, tannins, steroids, reducing sugar, phenolic compounds and higher saponin content

Results from HPLC analysis showed that an aqueous extract does not contain thymoquinone which is cytotoxic component that present in Ns seed. On the other hand, hexane solvent is non-polar with polarity index 0 and ethanol is polar solvent with polarity index 5.2 [24]. Phytochemical investigation by [25] demonstrated the present of zerumbone, zerumbone epoxide, diferuloymethane, feruloylp-coumaroyl-metane, di-p-coumaroyl-methane sesquiterpenoids, flavonoids, aromatic compound and vanillin in ethanol extract of Zz. Furthermore, a study by [26] found that zerumbone and 6-methoxy-2E,9E-humuladien-8-one were the compounds in hexane extracts. Zerumbone is the cytotoxic material in the $\mathrm{Zz}$ rhizome.

Our research indicated that the higher concentration of test material, the lesser percentage of cell viability HL60 cells (Fig. 1). This suggests an increase in the toxic effects of the test material. $\mathrm{IC}_{50}$ is concentration that can inhibit cell growth by $50 \%$ cell line. The smaller the $\mathrm{IC}_{50}$ of a compound the more toxic compound it was. Cytotoxic activity of PE extract of Ns is higher than aqueous extract. Research suggests that PE is one of non-polar solvents commonly used to attract lipid, wax, fat and resin [22]. Therefore, it is possible for thymoquinone largely attracted by solvent PE. The result obtained proved that the $\mathrm{IC}_{50} \mathrm{PE}$ of Ns extracts have anticancer activity as reported by [27] who indicated that anticancer activity will present when the $\mathrm{IC}_{50}$ value is less than $1000 \mathrm{ug} / \mathrm{ml}$. For the test material of $\mathrm{Zz}$, both $\mathrm{HEX}$ and ET extracts of $\mathrm{Zz}$, could exert a strong dose dependent cytotoxicity tu human myeloid leukemia (HL60) cells in vitro as assessed by the inhibitory effects in MTT assay. However, HEX extract showed a marginally higher activity than ethanolic extract at all concentration. It is because polarity hexane could attract more zerumbone as compared to ethanol which leads to more cytotoxic activity of hexane. Comparing the cytotoxic potential of these two plant species, $\mathrm{Zz}$ species showed more potent than $\mathrm{Ns}$ as anticancer of human myeloid leukemia (HL60) cells. This might be because of HL60 cells is more resistance to the activity of Ns species. These findings suggest that different solvent, cancer cell line, extraction method, and plant species will exhibit different cytotoxic effects. It is in agreement with the work by [28], who reported the cytotoxicity effects of aqueous extract of Ns on the other cells which is against HepG2 cells was $6 \mathrm{mg} / \mathrm{ml}$. Although our study showed that aqueous extracts on Ns is non-cytotoxic on HL60 cells, but the work by [29] revealed that aqueous extract of Ns was strong cytotoxic on a lot of cancer cells. The therapeutic value of any drug depends not only on its clinically efficacy, but also in its lack of toxic side-effects [30]. V79 cell is untargeted normal cell and derived from Chinese hamster lung. PE extract of Ns has potential as therapeutic anticancer because it has cytotoxic effects on HL60 and non toxic to normal cell V79. Previous research by [31] revealed that an increase in cytotoxicity effect of Ns is non toxic to normal cell, this found to be consistence with our studies. On the other hand, HEX extracts of Zz has cytotoxic effects on both HL60 and V79 cells. PLE extract of $\mathrm{Zz}$ showed toxic effects on normal V79 cells. These findings speculate that Ns and $\mathrm{Zz}$ might be targeting the different features that is present in several types of cells. 
Apoptosis is a crucial mode of cell death of cancer pathogenesis. Clinical treatments need apoptosis as an essential process in the pathogenesis of cancer [32]. In the mode of cell death analysis, Ns extracts effectively killed HL60 cells up to $90 \%$ in apoptosis form. In contrast, $\mathrm{Zz}$ extract caused both forms of cell death which are $50 \%$ apoptosis and $4 \%$ necrosis. Our data showed that Ns and Zz capable to enhance apoptosis as compared to etoposide and the percentage of apoptosis is higher compared to necrosis. This is consistent with a clinical use requirement as chemotherapeutic drugs should elicit apoptosis rather than necrosis [33]. The present study showed that Ns extract were more sensitive to HL60 cells in VITC annexin-V assay compared to MTT assay. In cell viability assay, $670 \mathrm{ug} / \mathrm{ml}$ of Ns extract reduced $37 \%$ of cell viability in HL60 for 24 hour of treatment. In contrast, $90 \%$ of cell death was noticed in VITC annexin-V assay of $670 \mathrm{ug} / \mathrm{ml}$ Ns treated for 24 hour. Therefore, the findings indicate that there are no significance correlation between MTT assay and VITC annexin-V which could be due to different parameters measured in each assay.

\section{CONCLUSION}

In conclusion, this study indicates that PE extract of Ns and HEX extract of Zz have shown cytotoxic effect on HL60 cells and triggers apoptotic cell death. PE extract of Ns is less effective as anti cancer therapeutic agents as compared to HEX extract $\mathrm{Zz}$ for human myeloid leukemia, however, they are able to prevents non-tumor tissues (V79) from sustaining chemotherapy-induced damage. Therefore, PLE extraction method has shown the potential to be developed as nutraceuticals for preventing the progression of leukemia cancer.

\section{CONFLICT OF INTEREST}

The authors confirm that this article content has no conflicts of interest.

\section{ACKNOWLEDGEMENTS}

The authors which to thanks to Universiti Teknologi Mara (UiTM) for providing research grant. Likewise, the authors are greatful with UKM, Kuala Lumpur for their kind cooperation and for grant permission to utilised their Biocompatibility and Toxicology Laboratory at Faculty of Health Sciences, UKM.

\section{REFERENCES}

[1] Vuorelaa, P.; Leinonenb, M.; Saikkuc, P.; Tammelaa, P.; Rauhad, J. P.; Wennberge, T. Natural products in the process of finding new drug candidates. Curr. Med. Chem., 2004, 11, 1375-1389.

[2] Amr, A.; Hala, G.M.; Matthias, O.; Regine, S.S. Overview of Major Classes of Plant-Derived Anticancer Drugs. Int. J. Biomed. Sci., 2009, 5(1),1-11.

[3] Burkill., H.I. A dictionary of the economic products of the Malay Peninsula. Published on behalf of the Government of Malaysia \& Singapore by the Ministry of Agricultural and co-operatives, K. L., Malaysia 1923, pp. 966-967.

[4] Mohammad, A.R. Black Seed, Nigella Sativa, Deserves More Attention. J Ayub Med Coll Abbottabad. 2008, 20(2), 1-2

[5] Ali, B.H.; Blunden, G. Pharmacological and toxicological properties of Nigella sativa. Phytother. Res., 2003, 17, 299-305.

[6] Arslan, S.O.; Gelir, E.; Armutcu, F.; Coskun, O.; Gurel, A.; Sayan, H.; Celik, I.L. The protective effect of thymoquinone on ethanolinduced acute gastric damage in the rat. Nutr. Res., 2005, 25, 673680 .
[7] El-Najar., Chatili, M.; Moukadem, H.; Vourela, H.; Ocker, M.; Gandesiri, M.; Schneider, S.R.; Gali, M.H. Reactive oxygen species mediate thymoquinone induced apoptosis and activate ERK and JNK signaling. Apoptosis, 2010, 15, 183-195.

[8] Torres, M.P.; Ponnusamy, M.P.; Chakraborty, S.; Smith, L.M.; Das, S.; Arafat, H.A.; Batra, S.K. Effects of thymoquinone in the expression of mucin 4in pancreatic cancer cells: implications for the development of novel cancer therapies. Mol. Cancer Ther., 2010, 1535-7163.

[9] Hassan, S.A.; Ahmed, W.A.; Galeb, F.M.; EL-Taweel, M.A.; AbuBedair, F.A. In vitro challenge using thymoquinone on hepatocellular carcinoma (Hepg2) cell line. Irianian J. Pharm. Res., 2008, 7(4). 283-290.

[10] Al-Zubairi, Adel, S.; Ahmad, B.A.; Mohammed, Y.; Siddig, I.A.; Manal, M.E.; Syam, M. In vivo and In vitro Genotoxic Effects of Zerumbone. Caryologia, 2010, 63, 11-17.

[11] Perry, L.M. Medicinal plants of East and Southeast Asia. MITPress Camb. Mass USA. 1980, p. 436.

[12] Tillar, M. The Indonesian traditional beauty with Indonesian herbs. FAPA Congres (Ladies Programme), Denpasar, Bali, Indonesia. 1988, pp. 315-326.

[13] Kinghorn, A.D.; Fransworth, N.R.; Soejarto, D.D.; Cordell, G.A.; Pezzuto, J.M.; Udeani, G.O.; Wani, M.C.; Wall, M.E.; Navarro, H.A.; Kramer, R.A.; Menendez, A.T.; Fairchild, C.R.; Lane, K.E.; Forenza, S.; Vyas, D.M.; Lams, K.S.; Shu, Y.Z. Novel strategies for the discovery of plant-derived anticancer agents. Pure Appl. Chem.,1997, 71(9), 1611-1618

[14] Koshimizu, K.; Ohigashi, H.; Tokuda, H.; Kondo, A.; Yamaguchi, $\mathrm{K}$. Screening of edible plants against antitumor promoting activity. Cancer Lett., 1988, 39, 247-57.

[15] Noorashikin, M.D.; Saleh, M. M. Sanagi comparison of pressurized liquid extraction with soxhlet extraction in the determination of polycyclic aromatic hydrocarbons in soil. Malay J. Anal. Sci., 2009, 13( 1), 141-145.

[16] Valizadeh, N.; Zakeri, H.R..; Amin, asnafi, G.; Shafiee, A.; Sarkhail P.; Heshmat, R..; Sereshti, H.; Larijani, B. Impact of Black seed (Nigella sativa) extract on bone turnover markers in postmenopausal women with osteoporosis. DARU. J. Pharm. Sci., 2009, 17, 20-25.

[17] Faujan, N.H.; Alitheen, N.B.; Yeap, S.K.; Ali, A.M.; Muhajir, A.H.; Ahmad, F.B.H. Myeloid leukemia (HL-60) cell line. Afr. J. Biotechnol., 2010 , 9(38), 6387-6396.

[18] Bhuvan, p.; Raval, Taxal, G.; Shah, Jignesh, D.; Patell, Bhavik, A.; Patel1, Rajesh, K.; Patel1, Maulik, P.; Suthar. Potent anticancer activity of Nigella Sativa seeds. Arch. Appl. Sci. Res., 2010, 2 (1), 52-56.

[19] Neuzil, J.; Weber, T.; Gellert, N.; Weber, C. Selective cancer cell killing by <-tocopheryl succinate. Br. J. Cancer, 2000, 84(1), 87-89.

[20] Noorashikin, M.d.; Saleh, M. Marsin. Sanagi comparison of pressurized liquid extraction with soxhlet extraction in the determination of polycyclic aromatic hydrocarbons in soil. The Malaysian. J. Anal. Sci., 2009, 13(1): 141-14.

[21] Harbone, J.B Metode Fitokimia: Penuntun Cara Modern Menganalisis Tumbuhan, ITB, Bandung. 1989.

[22] Dinasari, E. Identifikasi Senyawa Metabolit Sekunder dari Ekstrak Bunga Kecombrang (Nicolia speciosa Horan) dan Uji Toksisitasnya dengan metode Brine Shrimp Test, Skripsi. Fakultas Sains dan Teknik jurusan MIPA Prodi Kimia Universitas Jenderal Soedirman Purwokerto. 2009, p. 17.

[23] Sameera, R.S.; Ira, T.; Prasanna, B.G.; Dilip, D.S.; Kamani, H.T. A comparison of the cytotoxic potential of standardized aqueous and ethanolic extracts of a polyherbal mixture comprised of Nigella sativa (seeds), Hemidesmus indicus (roots) and Smilax glabra (rhizome). Pharmacog. Res., 2010, 2(6), 335-342.

[24] Wahida, A.F. Extraction of Zingiber zerumbet (l) smith oil by using soxhlet extarction method. Faculty of Chemical \& Natural Resources Engineering Universiti Malaysia Pahang, 2010, 1-32.

[25] Golam, K.; Rowshanul, H.; Farjana, N.; Tanzima, Y.; Mohammad, A. R.; Mukhlesur, R..; Simon, G. Zederone from the rhizomes of Zingiber zerumbet and its antistaphylococcal Activity. Boletin Latinoamericano y del Caribe de Plantas Medicinales Aromáticas, 2010, 9(1), 63-68.

[26] Chung, I.M.; Kim, M.Y.; Park, W.H.; Moon, N.I. Histone deacetylase inhibitors from the rhizomes of Zingiber zerumbet. Pharmazie, 2008, 63(10), 774-6. 
[27] Meyer, T.; Nindl, I.; Schmook, T.; Ulrich,C.; Sterry, W.; Stockfleth, E. Induction Of Apoptosis By Toll-Like Receptor-7 Agonist In Tissue Cultures. Br. J. Dermatol., 2003, 149 (Suppl. 66), 9-13.

[28] Thabrew, M.I.; Ragai, R.M.; Mohammed, A.M.; Robin, D.H. Cytotoxic effects of a decoction of Nigella sativa, Hemidesmus indicus and Smilax glabra on human hepatoma HepG2 cells. J. Life Sci., 2005, 77, 1319-1330.

[29] Swamy, S.M.K.; Tan B.K.H. Extraction, isolation and characterization of anti-tumor principle, alpha-hederin, from the seeds of Nigella sativa. Planta Med., 2001, 67, 29-32.

[30] Salomi, N.J.; Nair, S.C.; Jayawardhanan, K.K.; Verghese, C.D.; Panikkar, K.R.. Antitumor principles from Nigella sativa seeds. Cancer Lett., 1992, 63, 41-46.
[31] Aggarwal, B.B.; Kunnumakkara, A.B.; Harikumar, K.B.; Tharakan, S.T.; Sung, B.; Anand, P. Potential of spice-derived phytochemicals for cancer prevention. Planta Med., 2008, 74(13), 1560-1569.

[32] Rooney, S.; Ryan, M.F. Modes of action of alpha-hederin and thymoquinone, active constituents of Nigella sativa. Against Hep-2 cancer cells. Anticancer Res., 2005, 25, 4255-4259.

[33] Stoev. S.; Denev. S.; Dutton.M.; Nkosi.B.; J. Cytotoxic Effect of Some Mycotoxins and their Combinations on Human Peripheral Blood Mononuclear Cells as Measured by the MTT Assay. Open Toxinol., J., 2009, 2, 1-8.

Received: May 29, 2013

(C) Norfazlina et al.; Licensee Bentham Open.

This is an open access article licensed under the terms of the Creative Commons Attribution Non-Commercial License (http://creativecommons.org/licenses/by$\mathrm{nc} / 3.0 /$ ), which permits unrestricted, non-commercial use, distribution and reproduction in any medium, provided the work is properly cited. 